\title{
PCR targeting Plasmodium mitochondrial genome of DNA extracted from dried blood on filter paper compared to whole blood
}

\author{
Gro EA Strøm ${ }^{1,2^{*}}$, Sabrina Moyo ${ }^{1,3}$, Maulidi Fataki ${ }^{3,4}$, Nina Langeland ${ }^{1,5}$ and Bjørn Blomberg ${ }^{1,2}$
}

\begin{abstract}
Background: Monitoring mortality and morbidity attributable to malaria is paramount to achieve elimination of malaria. Diagnosis of malaria is challenging and PCR is a reliable method for identifying malaria with high sensitivity. However, blood specimen collection and transport can be challenging and obtaining dried blood spots (DBS) on filter paper by finger-prick may have advantages over collecting whole blood by venepuncture.

Methods: DBS and whole blood were collected from febrile children admitted at the general paediatric wards at a referral hospital in Dar es Salaam, Tanzania. DNA extracted from whole blood and from DBS was tested with a genus-specific PCR targeting the mitochondrial Plasmodium genome. Positive samples by PCR of DNA from whole blood were tested with species-specific PCR targeting the 18S rRNA locus, or sequencing if species-specific PCR was negative. Rapid diagnostic test (RDT) and thin blood smear microscopy was carried out on all patients where remnant whole blood and a blood slide, respectively, were available.

Results: Positivity of PCR was 24.5 (78/319) and 11.2\% (52/442) by whole blood and DBS, respectively. All samples positive on DBS were also positive on Plasmodium falciparum species-specific PCR. All RDT positive cases were also positive by DBS PCR. All but three cases with positive blood slides were also positive by DBS.

Conclusions: In this study, PCR for malaria mitochondrial DNA extracted from whole blood was more sensitive than from DBS. However, DBS are a practical alternative to whole blood and detected approximately the same number of cases as RDTs and, therefore, remain relevant for research purposes.
\end{abstract}

Keywords: Malaria, PCR, Filter paper, Dried blood spots/DBS, Chelex, InstaGene Matrix

\section{Background}

Malaria killed approximately 627,000 people, mostly children in sub-Saharan Africa, in 2012 and remains an endemic disease in 97 countries. Globally it is a major health concern, especially in low-resource settings [1].

The diagnosis of malaria is challenging and the conventional, gold standard, diagnostic method using blood smear microscopy lacks sensitivity and specificity in many malariaendemic settings [2-4]. Polymerase chain reaction (PCR) is a molecular technique that is often used for research purposes $[5,6]$. Conventionally, PCR has been performed on DNA

\footnotetext{
* Correspondence: gro_strom@hotmail.com

'Department of Clinical Science, University of Bergen, Bergen, Norway ${ }^{2}$ National Centre for Tropical Infectious Diseases, Department of Medicine, Haukeland University Hospital, Bergen, Norway

Full list of author information is available at the end of the article
}

extracted from whole blood. However, PCR amplification of Plasmodium DNA extracted from dried blood spots (DBS) on filter paper, rather than from whole blood, is a method that can be very useful in low-resource settings and is being used increasingly [7]. The use of DBS allows material to be collected in rural areas and stored at room temperature without the need of a cold chain. DBS require less blood than when whole blood is used for PCR and can be collected by finger-prick, which is minimally invasive compared to conventional methods of whole blood collection by venepuncture. With falling numbers of malaria cases [8] and emerging artemisinin resistance $[9,10]$, precise malaria diagnostics and monitoring of malaria transmission is of increasing importance. Also, with a goal of malaria elimination becoming more relevant [1], monitoring malaria 
epidemiology, including submicroscopic quantities of malaria detected only by PCR $[11,12]$, is necessary. It has been shown in some studies that PCR on DNA extracted from filter paper is less sensitive than PCR done on DNA extracted from whole blood [13], but the discrepancies found are not very remarkable. Ataei et al. found $42.7 \%$ positive for Plasmodium species by PCR on filter paper and $53.3 \%$ positive on whole blood [7], while a study by Proux et al. showed a smaller reduction in malaria detection by DBS as compared to whole blood [14]. Another study showed a ten- to 100 -fold decrease in sensitivity when using DBS as compared to whole blood [15].

The aim of this study was to compare detection of malaria by Plasmodium PCR of DNA extracted from DBS and from whole blood. Additionally, positivity of PCR from the two extraction methods and results of speciesspecific PCR, RDT and microscopy were compared.

\section{Methods}

\section{Data collection}

A total of 469 febrile children admitted to the general paediatric wards at Muhimbili National Hospital in Dar es Salaam, Tanzania in 2009 were included in the study after informed, written consent was obtained from the child's parent or guardian by signature or thumbprint. DBS were obtained from 442 of the study participants and they were prepared by dropping two drops of venous blood, collected with a syringe at the same time as other blood tests were taken, on a segment of a What$\operatorname{man}^{\circledast}$ Schleicher \& Schuell filter paper, grade 589/2 (Whatman GmbH, Dassel, Germany). The DBS was stored in a sealed, airtight plastic pocket after airdrying completely. The DBS were transported and stored protected from sunlight and after initial storage at approximately $25^{\circ} \mathrm{C}$ for three to nine months they were stored for about three-and-a-half years at $-20^{\circ} \mathrm{C}$ until DNA extraction was performed [16,17]. A vial of venous blood with EDTA was only obtained for the study from 319 of the 469 included children (of which 303 also had DBS available) and the remaining content in the vial after routine haematological tests were performed was stored for two to two-and-a-half years at $-20^{\circ} \mathrm{C}$ for ensuing DNA extraction. DBS and whole blood were missing from some of the patients due to practical and communicational challenges encountered during the data collection. DBS and EDTA blood vials were transferred to the University of Bergen using the Material Transfer Agreement of Muhimbili University of Health and Allied Sciences (MUHAS) and the EDTA blood samples were kept frozen using dry ice during transport.

\section{DNA extraction}

Harris Uni-Core ${ }^{\mathrm{TM}}$ puncher (Qiagen, Hilden, Germany) was used to punch out six pieces (or fewer if fewer than six punches were available) of filter paper with dried blood $3 \mathrm{~mm}$ in diameter. The puncher was cleaned as described elsewhere (Strom GE, Fataki M, Langeland N, Blomberg B: Comparison of four methods for extracting DNA from dried blood on filter paper for PCR targeting the mitochondrial Plasmodium genome, unpublished) and blank filter paper pieces punched out in the last step of the washing process were subjected to DNA extraction, followed by PCR between random samples to ensure no transfer of parasite DNA between samples using this cleaning method.

DNA was extracted from the DBS using a method with Chelex- $100^{\circ}$ Molecular Biology Grade Resin (Bio-Rad Laboratories, Hercules, CA, USA) and soaked in $0.5 \%$ saponin in phosphate buffered saline (PBS) solution overnight, as previously described as the method with the lowest limit of detection $(0.5$ parasites $/ \mu \mathrm{l})$ among the currently most used methods for DNA extraction from DBS (Strom GE, Fataki M, Langeland N, Blomberg B: Comparison of four methods for extracting DNA from dried blood on filter paper for PCR targeting the mitochondrial Plasmodium genome, unpublished). DNA was also extracted from $200 \mu \mathrm{l}$ whole blood (venous blood collected in a vial with EDTA anti-coagulant) using QIAamp ${ }^{\circ}$ DNA Blood Mini Kit (Qiagen, Hilden, Germany) as described by the manufacturer, and eluted in a final volume of $100 \mu \mathrm{l}$.

\section{PCR}

A genus-specific PCR targeting Plasmodium mitochondrial genome, as described by Haanshuus et al. [18], but with a primer concentration of $1 \mu \mathrm{M}$, was performed on DNA extracted from whole blood. The PCR method used on the DBS was the same as above but employed the producer-recommended HotStarTaq Plus DNA polymerase (Qiagen, Hilden, Germany) and CoralLoad PCR buffer (Qiagen, Hilden, Germany), and therefore step one at $95^{\circ} \mathrm{C}$ in the cycling parameters had a duration of five rather than 15 minutes. The final PCR reaction volume was $20 \mu \mathrm{l}$ including $2 \mu \mathrm{l}$ template. Amplification was done using GeneAmp PCR System 9700 (Applied Biosystems, Carlsbad, CA, USA). For species identification, species-specific PCR targeting the $18 \mathrm{~S}$ gene for P. falciparum, Plasmodium vivax, Plasmodium malariae and Plasmodium ovale was done on all whole blood samples positive by genus-specific PCR as described by Haanshuus et al. [18]. Those negative by species-specific PCR were sequenced. Analysis was done by electrophoresis using $2 \%$ SeaKem $^{\mathrm{TM}}$ agarose gel (Lonza, Rockland, ME, USA) with $1 \mathrm{X}$ GelRed $^{\mathrm{TM}}$ (Biotium, Hayward, CA, USA).

Slides for research microscopy were obtained for 403 of the patients and enough blood remained to perform RDT for 271 study participants. Microscopy and RDTs were performed as described elsewhere [2]. 


\section{Ethics}

A research permit was obtained from the Tanzania Commission for Science and Technology $(\mathrm{COSTECH})$, and ethical clearance was received from the appropriate bodies at MUHAS and MNH and from the Regional Committee for Medical and Health Research Ethics, Western Norway. The study was done in collaboration between MUHAS/MNH and the University of Bergen/Haukeland University Hospital, Norway.

\section{Results}

Of the DBS samples, 52/442 (11.2\%) were positive, as compared to $78 / 319(24.5 \%)$ of the whole blood samples. Of those positive by PCR on whole blood, 46.1\% (35/76) were negative on filter paper. All patients positive on PCR of DNA extracted from DBS were also positive on PCR for P. falciparum for patient samples where PCR on whole blood was done. None was only positive by sequencing. No other Plasmodium species were detected other than P. falciparum. All those positive by RDT (36) were also positive by PCR of DBS. However, one case was positive on PCR of DBS that was negative by RDT. Of those negative on PCR from DBS and where research blood smears were available, three $(0.7 \%)$ were positive on research microscopy and one of these was also negative on whole blood PCR. PCR of DNA extracted from DBS detected 25 more positive cases than were detected by research microscopy (22 positive cases).

Sensitivities, specificites, positive predictive value (PPV), and negative predictive value (NPV) of PCR on DNA from DBS, research microscopy and RDT when compared to PCR of DNA from whole blood are found in Table 1.

\section{Discussion}

The study aimed to compare Plasmodium genus-specific PCR of DNA extracted from whole blood and DNA extracted from filter paper (DBS) taken from febrile children admitted to general paediatric wards at a referral hospital in Tanzania. The number of participants positive by PCR of DNA from whole blood was almost twice as many as those positive by DNA from DBS. This was surprising given the low limit of detection of both the extraction method (Strom GE, Fataki M, Langeland N, Blomberg B: Comparison of four methods for extracting DNA from dried blood on filter paper for PCR targeting the mitochondrial Plasmodium genome, unpublished) and of the PCR method used [18]. The Chelex-100 based method for DNA extraction from DBS used in this study previously proved to be the method for DNA extraction from DBS with the lowest limit of detection when compared to several other commonly used extraction methods (Strom GE, Fataki M, Langeland N, Blomberg B: Comparison of four methods for extracting DNA from dried blood on filter paper for PCR targeting the mitochondrial Plasmodium genome, unpublished). It is a method that is cost-effective and simple and has also previously been used in many malaria-studies using DBS [16,19-23].

All those positive by PCR of DBS were also positive on $P$. falciparum PCR targeting the $18 \mathrm{~S}$ rRNA gene. The mitochondrial genome is present in more copies per parasite than the $18 \mathrm{~S}$ gene [18]. This may indicate that the cases positive on DBS were cases with higher parasitaemia with enough copies of the $18 \mathrm{~S}$ locus as well as the mitochondrial genome to result in both positive genus- and species-specific PCR. The conventional singleamplification PCR used was chosen as it previously has been performed non-inferiorly to a reference nested-PCR and is less time-consuming and previously has performed well $[2,18]$ (Strom GE, Fataki M, Langeland N, Blomberg $\mathrm{B}$ : Comparison of four methods for extracting DNA from dried blood on filter paper for PCR targeting the mitochondrial Plasmodium genome, unpublished).

When using DBS rather than whole blood as a source of DNA for PCR the concentration of DNA is much lower. In six 3-mm punches of DBS there is approximately $25 \mu \mathrm{l}$ blood (a $50 \mu \mathrm{l}$ DBS gives an average 12 punches per DBS), which, using the DNA extraction method used in this study, ends in a final elution volume of approximately $80 \mu \mathrm{l}$ template. Using the QIAamp DNA Blood Mini Kit, $200 \mu \mathrm{l}$ whole blood resulted in a final elution volume of $100 \mu \mathrm{l}$. This results in more than five times greater DNA concentration using the whole blood method compared to the DBS method. This is likely an important contributing factor to the lower sensitivity of the DBS method as compared to the whole blood method.

Storage of DBS has previously been shown to influence the sensitivity of PCR performed on extracted DNA. One study reported sensitivity to decrease after six years

Table 1 Sensitivity, specificity, PPV and NPV of PCR of DBS, study microscopy and RDT with PCR of whole blood as a gold standard

\begin{tabular}{lcccr}
\hline Diagnostic method & Sens (\%) & Spec (\%) & PPV (\%) & NPV (\%) \\
\hline DBS PCR & $41 / 76(53.9)$ & $227 / 227(100.0)$ & $41 / 41(100.0)$ & $227 / 262(86.6)$ \\
Study micro & $20 / 76(26.3)$ & $227 / 228(99.6)$ & $20 / 21(95.2)$ & $227 / 283(80.2)$ \\
RDT & $38 / 71(53.5)$ & $199 / 199(100.0)$ & $38 / 38(100.0)$ & $199 / 232(85.8)$ \\
\hline
\end{tabular}

PPV: positive predictive value; NPV: negative predictive value; $P C R$ : polymerase chain reaction; DBS: dried blood spot; $R D T$ : rapid diagnostic test for malaria; Sens: sensitivity; Spec: specificity; micro: microscopy. 
[24] and the samples used in the current study had been stored for four to four-and-a-half years before analysis. However, another study actually showed an increased sensitivity after storage of DBS for more than four years [25] though these results have not been reproduced and the study was done without using proper controls. Also this increased sensitivity was no longer present after purification steps were repeated of the more recently collected samples. Not many studies have been done comparing PCR of whole blood and filter paper, but many studies have used only DBS as a source of DNA for PCR of participants.

The use of DBS is practical for studies of anti-malarial resistance genes [26], anti-malarial drug concentrations in blood [27] and for reliable species identification as well as monitoring malaria epidemiology, including parasitic genotyping to consider whether return of parasitaemia after a short time is due to re-infection or recrudescence [28]. It detects more cases than microscopy, although the sensitivity found in this study, with PCR of DNA extracted from whole blood as the gold standard, was not much higher than for RDTs $(53.9 \%$ (Table 1), and 52.9\% (Additional file 2 of reference [2]), respectively). A study done in Senegal in an urban setting, showed a higher discrepancy between DBS and microscopy results with $15.2 \%$ of asymptomatic study participants positive by PCR of DBS but negative on thick blood smear microscopy [29]. The sensitivity of the RDT in this study was better than previously shown in a similar comparison of PCR of DBS and RDT by Fancony et al. [30]. DBS have the advantage that they provide DNA, which can be analysed for the abovementioned additional purposes. The current study is representative of how field conditions may truly be, with high temperatures and challenging DBS preparation and storage conditions. This may also have contributed to the lower than expected sensitivity of PCR on DBS as high temperatures initially during storage may have reduced DNA quality [15]. The applicability of the results of the study is broad and realistic in a resource-poor, malaria-endemic setting. The fact that different methods of DNA extraction, PCR and RDTs have been used in the various studies reduces the value of a detailed comparison.

\section{Conclusion}

Using the methodology followed in this work, the sensitivity of PCR for malaria on DNA extracted from DBS is approximately half of the sensitivity of PCR on DNA extracted from whole blood. Nonetheless the advantages of DBS when it comes to storage and transport may to some degree compensate for this when applying the use of DBS for research in rural settings where collection of whole blood is not possible. Use of DBS as a source of DNA for PCR could therefore be a convenient method for monitoring levels of malaria transmission in remote locations. As the results corresponded well to RDT results this may indicate that the most important and clinically relevant cases were found. The importance of the use of whole blood samples being significantly superior to DBS should be investigated further with studies of low-level parasitaemia using quantitative PCR or other quantitative techniques.

\section{Competing interests}

The authors declare that they have no competing interests.

\section{Authors' contributions}

GEAS and BB were involved in all stages of this study. SM was involved in the design of the study and coordination of fieldwork. MF coordinated the fieldwork. NL was involved in the design of the study. All authors contributed to the data interpretation and writing of the manuscript. All authors have read and approved the final manuscript.

\section{Acknowledgements}

Thanks to all the staff at paediatric wards at Muhimbili National Hospital in Dar es Salaam for their assistance in recruiting study participants and collecting samples.

\section{Author details}

Department of Clinical Science, University of Bergen, Bergen, Norway. ${ }^{2}$ National Centre for Tropical Infectious Diseases, Department of Medicine, Haukeland University Hospital, Bergen, Norway. ${ }^{3}$ Muhimbili University of Health and Allied Sciences, Dar es Salaam, Tanzania. ${ }^{4}$ Muhimbili National Hospital, Dar es Salaam, Tanzania. ${ }^{5}$ Department of Medicine, Haukeland University Hospital, Bergen, Norway.

Received: 3 December 2013 Accepted: 2 April 2014 Published: 7 April 2014

\section{References}

1. WHO: World Malaria Report 2013. Geneva: World Health Organization; 2013

2. Strom GE, Haanshuus CG, Fataki M, Langeland N, Blomberg B: Challenges in diagnosing paediatric malaria in Dar es Salaam, Tanzania. Malar $J$ 2013, 12:228.

3. Reyburn H, Mbatia R, Drakeley C, Carneiro I, Mwakasungula E, Mwerinde O, Saganda K, Shao J, Kitua A, Olomi R, Greenwood BM, Whitty CJ: Overdiagnosis of malaria in patients with severe febrile illness in Tanzania: a prospective study. BMJ 2004, 329:1212.

4. Wongsrichanalai C, Barcus MJ, Muth S, Sutamihardja A, Wernsdorfer WH: A review of malaria diagnostic tools: microscopy and rapid diagnostic test (RDT). Am J Trop Med Hyg 2007, 77:119-127.

5. Hanscheid T, Grobusch MP: How useful is PCR in the diagnosis of malaria? Trends Parasitol 2002, 18:395-398.

6. Morassin B, Fabre R, Berry A, Magnaval JF: One year's experience with the polymerase chain reaction as a routine method for the diagnosis of imported malaria. Am J Trop Med Hyg 2002, 66:503-508.

7. Ataei $S$, Nateghpour M, Hajjaran H, Edrissian GH, Foroushani AR: High specificity of semi-nested multiplex PCR using dried blood spots on DNA Banking Card in comparison with frozen liquid blood for detection of Plasmodium falciparum and Plasmodium vivax. J Clin Lab Anal 2011, 25:185-190.

8. Murray CJ, Rosenfeld LC, Lim SS, Andrews KG, Foreman KJ, Haring D, Fullman N, Naghavi M, Lozano R, Lopez AD: Global malaria mortality between 1980 and 2010: a systematic analysis. Lancet 2012, 379:413-431.

9. Phyo AP, Nkhoma S, Stepniewska K, Ashley EA, Nair S, McGready R, ler Moo C, Al-Saai S, Dondorp AM, Lwin KM, Singhasivanon P, Day NPJ, White NJ, Anderson TJC, Nosten F: Emergence of artemisinin-resistant malaria on the western border of Thailand: a longitudinal study. Lancet 2012, 379:1960-1966.

10. Dondorp AM, Nosten F, Yi P, Das D, Phyo AP, Tarning J, Lwin KM, Ariey F, Hanpithakpong W, Lee SJ, Ringwald P, Silamut K, Imwong M, Chotivanich K, Lim P, Herdman T, An SS, Yeung S, Singhasivanon P, Day NP, Lindegardh N, 
Socheat $\mathrm{D}$, White NJ: Artemisinin resistance in Plasmodium falciparum malaria. N Engl J Med 2009, 361:455-467.

11. Bottius E, Guanzirolli A, Trape JF, Rogier C, Konate L, Druilhe P: Malaria: even more chronic in nature than previously thought; evidence for subpatent parasitaemia detectable by the polymerase chain reaction. Trans R Soc Trop Med Hyg 1996, 90:15-19.

12. Okell LC, Bousema T, Griffin JT, Ouedraogo AL, Ghani AC, Drakeley CJ: Factors determining the occurrence of submicroscopic malaria infections and their relevance for control. Nat Commun 2012, 3:1237.

13. Al-Harthi SA, Jamjoom MB: PCR assay in malaria diagnosis using filter paper samples from Jazan region, Saudi Arabia. J Egypt Soc Parasitol 2008, 38:693-706

14. Proux S, Suwanarusk R, Barends $M$, Zwang J, Price R, Leimanis $M$, Kiricharoen L, Laochan N, Russell B, Nosten F, Snounou G: Considerations on the use of nucleic acid-based amplification for malaria parasite detection. Malar J 2011, 10:323.

15. Farnert A, Arez AP, Correia AT, Bjorkman A, Snounou G, do Rosario V: Sampling and storage of blood and the detection of malaria parasites by polymerase chain reaction. Trans $R$ Soc Trop Med Hyg 1999, 93:50-53.

16. Moll K, Ljungstrom I, Perlmann H, Scherf A, Wahlgren M: Methods in Malaria Research Fifth Edition. Manassas, Virginia, USA: Malaria Research and Reference Reagent Resource Center (MR4); 2008.

17. Pritsch M, Wieser A, Soederstroem V, Poluda D, Eshetu T, Hoelscher M, Schubert S, Shock J, Loescher T, Berens-Riha N: Stability of gametocytespecific Pfs25-mRNA in dried blood spots on filter paper subjected to different storage conditions. Malar J 2012, 11:138.

18. Haanshuus C, Mohn S, Morch K, Langeland N, Blomberg B, Hanevik K: A novel, single-amplification PCR targeting mitochondrial genome highly sensitive and specific in diagnosing malaria among returned travellers in Bergen, Norway. Malar J 2013, 12:26.

19. Wooden J, Kyes S, Sibley CH: PCR and strain identification in Plasmodium falciparum. Parasitol Today 1993, 9:303-305.

20. Wangai LN, Karau MG, Njiruh PN, Sabah O, Kimani FT, Magoma G, Kiambo $\mathrm{N}$ : Sensitivity of microscopy compared to molecular diagnosis of $P$. falciparum: implications on malaria treatment in epidemic areas in kenya. Afr J Infect Dis 2011, 5:1-6.

21. Plowe CV, Djimde A, Bouare M, Doumbo O, Wellems TE: Pyrimethamine and proguanil resistance-conferring mutations in Plasmodium falciparum dihydrofolate reductase: polymerase chain reaction methods for surveillance in Africa. Am J Trop Med Hyg 1995, 52:565-568.

22. Shekalaghe S, Drakeley C, Gosling R, Ndaro A, van Meegeren M, Enevold A, Alifrangis M, Mosha F, Sauerwein R, Bousema T: Primaquine clears submicroscopic Plasmodium falciparum gametocytes that persist after treatment with sulphadoxine-pyrimethamine and artesunate. PLoS One 2007, 2:e1023.

23. Pearce RJ, Drakeley C, Chandramohan D, Mosha F, Roper C: Molecular determination of point mutation haplotypes in the dihydrofolate reductase and dihydropteroate synthase of Plasmodium falciparum in three districts of northern Tanzania. Antimicrob Agents Chemother 2003, 47:1347-1354

24. Hwang J, Jaroensuk J, Leimanis M, Russell B, McGready R, Day N, Snounou $G$, Nosten F, Imwong M: Long-term storage limits PCR-based analyses of malaria parasites in archival dried blood spots. Malar J 2012, 11:339.

25. Chaorattanakawee S, Natalang O, Hananantachai H, Nacher M, Brockman A, Krudsood S, Looareesuwan S, Patarapotikul J: Storage duration and polymerase chain reaction detection of Plasmodium falciparum from blood spots on filter paper. Am J Trop Med Hyg 2003, 69:42-44.

26. Gadalla NB, Abdallah TM, Atwal S, Sutherland CJ, Adam I: Selection of pfdhfr/pfdhps alleles and declining artesunate/sulphadoxinepyrimethamine efficacy against Plasmodium falciparum eight years after deployment in eastern Sudan. Malar J 2013, 12:255.

27. Valecha N, Mohanty S, Srivastava P, Sharma S, Tyagi P, Bergqvist Y, Ringwald $P$ : Efficacy of artemether-lumefantrine in area of high malaria endemicity in India and its correlation with blood concentration of lumefantrine. Am J Trop Med Hyg 2012, 86:395-397.

28. WHO: Guidelines for the Treatment of Malaria. 2nd edition. Geneva: World Health Organization; 2010.

29. Diallo A, Ndam NT, Moussiliou A, Dos Santos S, Ndonky A, Borderon M Oliveau S, Lalou R, Le Hesran JY: Asymptomatic carriage of plasmodium in urban Dakar: the risk of malaria should not be underestimated. PLoS One 2012, 7:e31100.

30. Fancony C, Sebastiao Y, Pires J, Gamboa D, Nery S: Performance of microscopy and RDTs in the context of a malaria prevalence survey in Angola: a comparison using PCR as the gold standard. Malar J 2013, 12:284.

doi:10.1186/1475-2875-13-137

Cite this article as: Strøm et al:: PCR targeting Plasmodium mitochondrial genome of DNA extracted from dried blood on filter paper compared to whole blood. Malaria Journal 2014 13:137.

\section{Submit your next manuscript to BioMed Central and take full advantage of:}

- Convenient online submission

- Thorough peer review

- No space constraints or color figure charges

- Immediate publication on acceptance

- Inclusion in PubMed, CAS, Scopus and Google Scholar

- Research which is freely available for redistribution 